\title{
ANALISIS KEMAMPUAN PEMECAHAN MASALAH SISWA BERDASARKAN LANGKAH IDEAL PROBLEM SOLVING
}

\author{
Fitri Indriyani*, Novi Andri Nurcahyono, Nur Agustiani \\ Program Studi Pendidikan Matematika, Fakultas Keguruan dan Ilmu Pendidikan \\ Jl. R. Syamsudin, SH. No. 50 Kota Sukabumi., Telp. (0266)218345/Fax. (0266)218342 \\ Universitas Muhammadiyah Sukabumi, Jawa Barat, Indonesia \\ *e-mail: fithriindri.28@gmail.com
}

\begin{abstract}
Abstrak. Penelitian ini bertujuan untuk mendeskripsikan kemampuan pemecahan masalah siswa SMP kelas VII berdasarkan langkah IDEAL. Jenis penelitian ini merupakan penelitian deskriptif kualitatif dengan desain penelitian studi kasus. Penentuan subjek menggunakan teknik purposive sampling didapat 3 siswa yang dijadikan subjek sesuai kemampuan pemecahnya yaitu kemampuan tinggi (S14), sedang (S9) dan rendah (S21). Instrumen penelitian berupa tes dengan bentuk soal uraian yang telah divalidasi dan wawancara semi terstruktur. Teknik pengumpulan data penelitian ini tes, wawancara dan dokumentasi. Analisis data meliputi reduksi data, penyajian data dan kesimpulan. Keabsahan data menggunakan triangulasi teknik. Hasil penelitian menunjukan subjek berkemampuan tinggi dapat melewati semua langkah pemecahan, hanya saja masih terkendala pada melaksanakan strategi terdapat kesalahan dalam operasi. Subjek sedang masih kesulitan dalam menuliskan informasi akan tetapi mengerti permasalahan, subjek hanya memiliki strategi yang tepat untuk 1 soal aja, subjek masih kurang dalam mengkaji hasil. Subjek berkemampuan rendah hanya mengerti permasalahan dan mengetahui informasi tanpa mempunyai strategi untuk menyelesaikannya.
\end{abstract}

Kata kunci: Kemampuan Pemecahan Masalah, IDEAL, deskriptif kualitatif

\begin{abstract}
This study aims to describe the problem solving skills of students of SMP class VII based on IDEAL step. This type of research is a qualitative descriptive research with case study research design. Determination of subjects using purposive sampling techniques obtained 3 students who made the subject according to ability of problem solvier that is high ability (S14), medium (S9) and low (S21). Research instruments are test and interview. The collection of research data is test, interview and documentation. Data analysis includes reduction, presentation and conclusions. Validitiy data using triangulation technique. The results showed that high-ability subjects can pass all the solving steps, it's just still constrained to implement the strategy there are errors in the operation. Subjects are still difficulties in writing information but understand the problem, the subject only has the right strategy for number 1 , the subject is still less in reviewing the results. Low-ability subjects only understand the problem and know the information without having a strategy to solve it.
\end{abstract}

Keywords: Problem Solving Abilities, IDEAL, qualitative descriptive

\section{Pendahuluan}

Salah satu tujuan pembelajaran matematika di sekolah pada kurikulum 2013 yang menyebutkan pemecahan masalah (problem solving) sebagai salah satu kemahiran yang harus dimiliki siswa. National Council of Teacher Mathematics (NTCM) menyebutkan pemecahan masalah menjadi salah satu kemampuan dasar dari empat kemampuan dasar lainnya yang harus dimiliki siswa setelah pembelajaran matematika (Ulya, 2015). Branca (Purnomo \& Mawarsari, 2014) berpendapat bahwa pemecahan masalah merupakan tujuan utama dalam pembelajaran matematika. Matematika menjadi tujuan utama dalam pembelajaran karena dengan melakukan pemecahan masalah siswa memperoleh proses menalar dan melakukan kreativitas dalam berpikir untuk mempelajari hal-hal baru dalam matematika dengan 
pemahaman yang lebih besar (Nissa, 2015). Sehingga pemecahan masalah merupakan cara yang sangat berguna untuk mempraktikan keterampilan matematika. Selain itu dengan kemampuan memecahkan masalah yang telah dipelajari dalam pembelajaran, siswa dapat mengaplikasikan dalam kehidupan.

Cara untuk mengasah kemampuan pemecahan masalah adalah dengan memberikan siswa soal pemecahan masalah. (Hartini, n.d.) mengungkapkan dengan memberikan soal cerita dapat menentukan kemampuan pemecahan masalah. Karena Soal cerita merupakan soal uraian yang menyajikan permasalah terkait dengan kehidupan sehari-hari. Selain itu menurut Hudojo (Nahdataeni \& Linawati, 2015) suatu soal dikatakan suatu masalah jika soal tersebut memberikan tantangan dan tidak dapat dikerjakan dengan proses rutin. Sehingga dengan pemberian soal cerita siswa merasa tertantang untuk mengerjakan soal tersebut agar kemampuan pemecahan masalah dapat diasah.

Salah satu materi pelajaran yang erat kaitannya dengan kehidupan sehari-hari adalah materi Persamaan Linier Satu Variabel (PLSV) dan Pertidaksamaan Linier Satu Variabel (PtLSV). Akan tetapi kemampuan pemecahan masalah dalam materi ini masih tergolong rendah. Hal ini berdasarkan pada hasil ulangan harian dengan bentuk soal uraian masih banyak siswa yang nilainya dibawah KKM. KKM yang ditetapkan untuk mata pelajaran matematika kelas VII sebasar 75. Pada kelas VII-D siswa yang belum tuntas sebanyak $74,36 \%$. Masih besarnya persentase siswa yang belum tuntas menandakan masih banyaknya siswa yang belum dapat memecahkan masalah dengan baik. Hasil tes awal yang dilakukan ke kelas VII pada materi persamaan linier satu variabel ditunjukan pada gambar berikut:

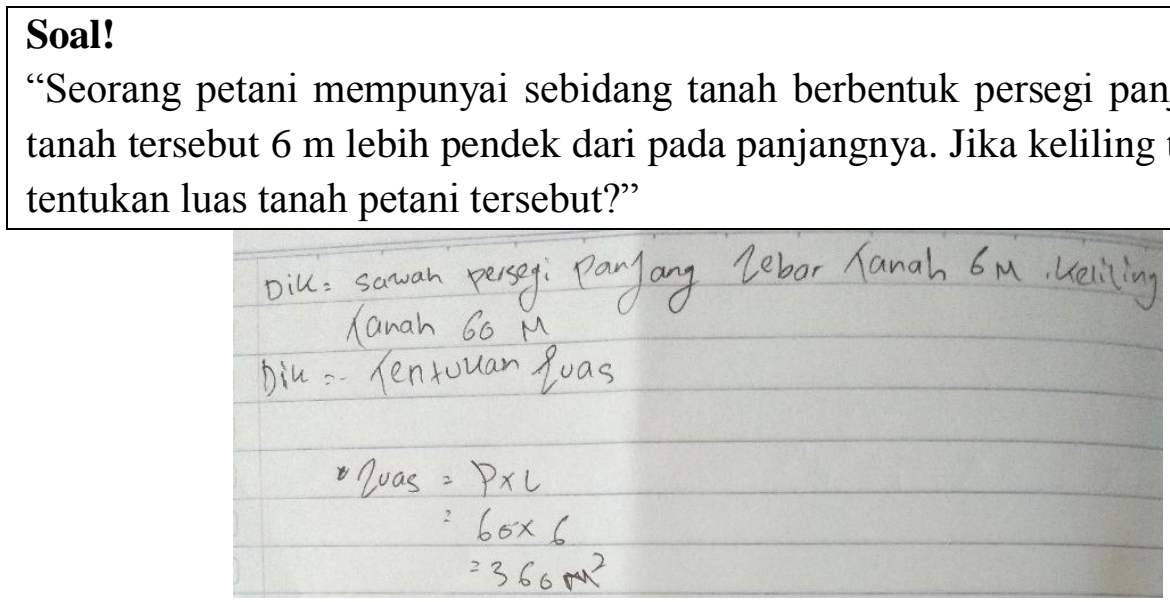

Gambar 1. Hasil Pengerjaan Siswa

Pada gambar 1 terlihat siswa kurang dalam menuliskan informasi yang diketahui pada soal. Kemudian strategi yang digunakanpun kurang tepat sehingga solusi yang dihasilkan tidak sesuai dengan yang tujuan masalah pada soal. Dengan demikian perlu dilakukan analisis lebih lanjut menggunakan strategi pemecahan masalah yang diperkenalkan oleh Bransford dan Stein yaitu langkah IDEAL problem solving yang memiliki 5 tahapan yaitu mengidentifikasi masalah, mendefinisikan tujuan, menggali strategi, melaksanakan strategi dan mengkaji kembali hasil didapat (Prasetya \& Widodo, 2012).

Langkah pemecahan IDEAL problem solving ini merupakan langkah pemecahan masalah yang rinci jika dibandingkan dengan langkah pemecahan Polya. Adapun langkah 
IDEAL problem solving ini, berdasarkan pada singkatan dari setiap huruf yang membentuk IDEAL. Terdiri dari 5 langkah pemecahan masalah yaitu (I-Identify problem) (Mengidentifikasi maasalah), D-Define goal (Menentukan tujuan), E-Explore possible strategies (Menggali strategi), A- Act on the strategy (Melaksanakan strategi), dan L-Look back and Learn (Mengkaji kembali). Pada pemecahan Polya menuliskan informasi yang dibutuhkan dan permasalah pada soal berada pada satu tahap yaitu tahap memahami masalah. Sedangkan pada IDEAL dalam menuliskan informasi yang dibutuhkan dan permasalahan pada soal berbeda tahapannya. Rincinya langkah IDEAL ini dapat memudahkan untuk menganalisis langkah pemecahan masalah manakah yang menyulitkan siswa sehingga siswa tidak memecahkan masalah. Dengan langkah yang rinci siswa dapat berpikir sistematis. Seperti yang diungkapkan (Widodo \& Purwaningsih, 2016) bahwa dalam menyelesaikan masalah siswa dituntut untuk berpikir secara sistematis. Oleh karena itu, maka perlu dilakukan penelitian terhadap kemampuan pemecahan masalah berdasarkan langkah IDEAL problem solving. Tujuan dilakukan penelitian ini untuk mendeskripsikan kemampuan pemecahan masalah yang dilakukan siswa pada materi PLSV dan PtLSV berdasarkan langkah IDEAL problem solving.

\section{Metode Penelitian}

Penelitian ini merupakan jenis penelitian deskriptif kualitatif dengan desain penelitian studi kasus. Penelitian kualitatif ini untuk memberikan gambaran pada kondisi objek yang alamiah dengan peneliti sebagai instrumen kunci. Penelitian ini dilaksanakan di SMP Negeri 8 Kota Sukabumi pada semester genap tahun ajaran 2017/2018. Waktu pengambilan data untuk penelitian ini dilaksanakan pada bulan April-Mei 2018. Subjek penelitian ini 29 orang siswa kelas VII D, kemudian diambil 3 orang siswa untuk diwawancarai berdasarkan hasil tes yang telah dikategorikan pada kemampuan tinggi, sedang dan rendah. Pengambilan subjek ini secara purposive sampling atau pengambilan subjek berdasarkan pada pertimbangan tertentu (Sugiyono, 2017). Teknik pengambilan data dilakukan dengan pemberian tes pemecahan masalah dan wawancara. Banyaknya soal adalah 4 butir yang terdiri dari 2 soal PLSV dan 2 soal PtLSV. Sebelum soal pemecahan masalah diteskan kepada subjek penelitian soal telah divalidasi kepada 3 validator. Validator terdiri dari 2 orang dosen pendidikan matematika UMMI dan satu guru mata pelajaran matematika. Setalah soal tes dinyatakan valid oleh validator soal diteskan kepada subjek penelitian. Setelah hasil tes dikoreksi dan dikelompokan kedalam kemampuan tinggi, sedang dan rendah dilakukan wawancara kepada 3 siswa yang terpilih. Wawancara yang digunakan adalah wawancara semi terstruktur untuk mengetahui lebih dalam kemampuan pemecahan masalah. Analisis data dilakukan secara interaktif dan terus menerus sampai tuntas. Kegiatan dari analisis data dilakukan dengan mereduksi data yang diperlukan untuk penelitian. Yaitu dengan memilih data-data pokok agar penelitian masih tetap fokus terhadap apa yang diteliti. Setelah itu data disajikan dalam bentuk uraian dan bagan. Setelah data direduksi dan disajikan langkah selanjutnya adalah disimpulkan sesuai dengan tujuan masalah atau menjawab rumusan masalah. Pengujian data atau validasi data dilakukan dengan triangulasi. Triangulasi yang dilakukan dalam penelitian ini adalah 
triangulasi teknik dengan mengecek data kepada sumber yang sama dengan teknik pengambilan data yang berbeda.

\section{Hasil Penelitian dan Pembahasan}

Berdasarkan tes yang dilakukan pada tanggal 3 Mei 2018 yang dilakukan di kelas VII D, hasil tes dikelompokan pada kategori tinggi, sedang dan rendah menggunakan standar deviasi. Pengelompokan ini sesuai dengan (Arikunto, 2010) menjelaskan untuk mengelompokan kemampuan matematika siswa tinggi, sedang dan rendah menggunakan standar deviasi. Pengelompokan dilakukan dengan menghitung rerata nilai pada tes dan standar deviasi. Kriteria pengelompokan kemampuan matematika siswa menurut (Arikunto, 2010). Berdasarkan hasil perhitungan rerata tes ini sebesar 59 dan standar deviasi sebesar 14. Berikut data hasil tes:

Tabel 1. Data Hasil Tes Pemecahan Masalah

\begin{tabular}{lccc}
\hline \multicolumn{1}{c}{ Kategori } & Banyak siswa & Siswa yang terpilih & Nilai siswa \\
\hline Tinggi $(\mathrm{T})$ & 5 & $\mathrm{~S} 14$ & 90 \\
Sedang $(\mathrm{S})$ & 18 & $\mathrm{~S} 9$ & 63 \\
Rendah $(\mathrm{R})$ & 6 & $\mathrm{~S} 21$ & 33 \\
\hline
\end{tabular}

Pada tabel 1 menjelaskan bahwa siswa yang masuk kategori tinggi sebanyak 5 orang, sedang 18 orang dan 6. Adapun siswa yang mewakili dari 3 kategori tersebut yaitu S14, S9 dan S21 dengan nilai 90, 63 dan 33. Lembar jawaban dari 3 subjek akan dianalisis lebih lanjut sesuai dengan langkah IDEAL problem solving dan dengan ketiga subjek tersebut dilakukuan wawancara. Wawancara dilakukan untuk mengkonfirmasi jawaban dalam proses pemecahan masalah serta kemungkinan temuan lainnya yang akan didapat pada saat wawancara.

IDEAL Problem Solving merupakan salah satu strategi pemecahan masalah yang diperkenalkan oleh Bransford dan Stein (Ulya, 2015). Terdapat beberapa strategi pemecahan masalah lainnya seperti yang dikemukakan Polya. Langkah-langkah dalam strategi pemecahan masalah IDEAL ini merupakan kepanjangan dari tiap-tiap huruf dalam IDEAL yaitu I-Identify problem) (Mengidentifikasi maasalah), D-Define goal(Menentukan tujuan), EExplore possible strategies (Menggali strategi), A- Act on the strategy (Melaksanakan strategi), dan L-Look back and Learn (Mengkaji kembali). Berdasarkan analisis jawaban ke 3 subjek terhadap langkah pemecahan masalah berdasarkan langkah IDEAL didapatkan hasil sebagai berikut: 


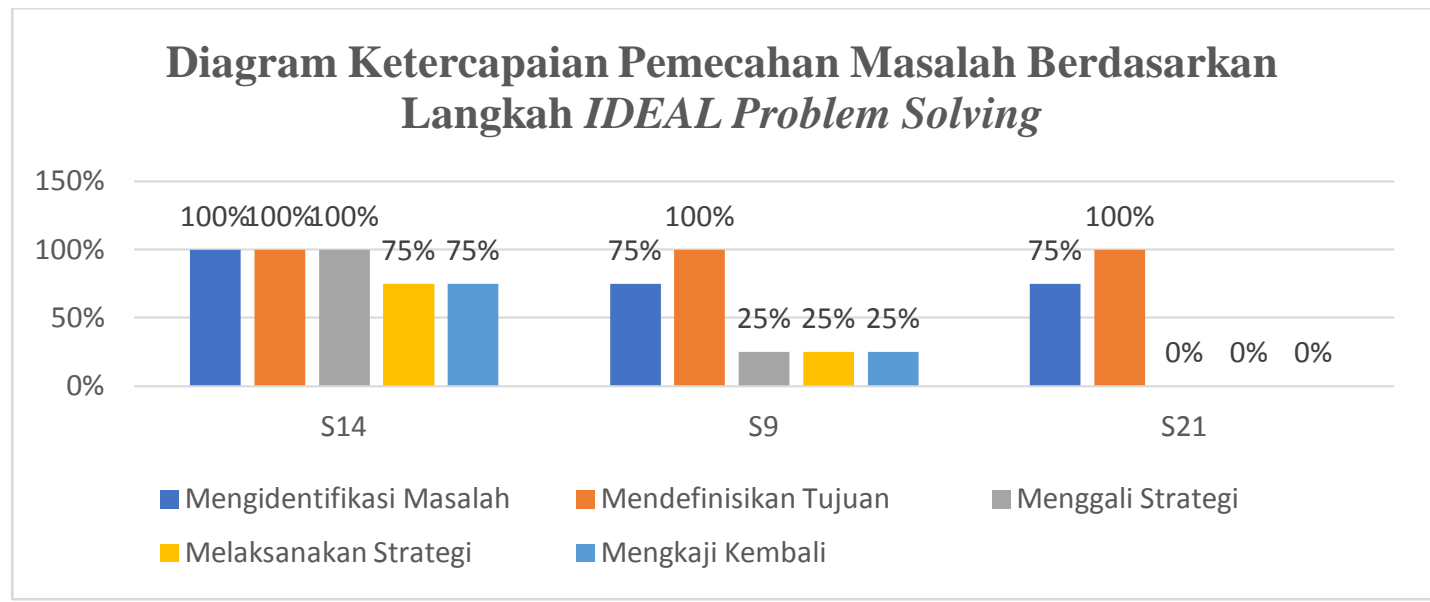

Gambar 2. Diagram Batang Ketercapaian Langkah IDEAL

Berdasarkan gambar 2 ketiga subjek memiliki kemampuan yang berbeda dalam memecahkan masalah. Dapat terlhat persentase dari ketercapaian dari semua subjek dalam memenuhi langkah penyelesaian IDEAL Problem Solving. Subjek S14 (T) memiliki lebih dari $50 \%$ dari setiap langkah. Kemudian untuk subjek S9 (S) dan S21 (R) hanya langkah mendefinisikan tujuan saja persentase yang lebih besar dibanding langkah lainnya. Bahkan untuk subjek S21 tidak dapat memenuhi langkah menggali strategi, melaksanakan strategi dan mengkaji kembali. Berikut analisis dan pembahasan langkah pemecahan masalah:

1. Mengidentifikasi masalah

Berdasarkan diagram pada gambar 2 hanya subjek S14 (T) memiliki persentase sebesar 100\%, artinya dari semua soal subjek S14 dapat mengidentifikasi masalah dengan baik. Kemudian untuk S9 (S) dan S21(R) sebesar 75\% artinya hanya 3 soal dapat memenuhi langkah ini.

Subjek S14 (T) dapat mengindentifikasi masalah dengan baik. Subjek S14 dapat menuliskan seluruh informasi yang dibutuhkan untuk memecahkan masalah. Hal ini sejalan dengan penelitian yang dilakukan oleh (Annizar, 2015) bahwa siswa berkemampuan tinggi cenderung menuliskan informasi yang diketahui dalam soal dengan lengkap. Kemudian dalam menuliskan informasi subjek S14 menuliskan secara singkat pada nomor 1 dan 2, sedangkan untuk nomor 3 dan 4 cenderung menggunakan kalimat dalam soal. Pada hasil wawancara subjek dapat menyebutkan informasi yanh dibutuhkan pada setiap soal dengan lengkap. Selain itu subjek S14 dapat mengidentifikasi masalah dengan benar terhadap jenis soal, subjek dapat membedakan soal persamaan dan pertidaksamaan.

Subjek S9 (S) dan subjek S21 (R) hanya dapat memenuhi langkah ini pada 3 soal saja. Subjek S9 (S) dapat memenuhi indikator mengidentifikasi hanya pada nomor 1, 2 dan 4. Untuk soal 1 dan 2 subjek dapat menuliskan informasi yang dibutuhkan dalam memecahkan masalah dengan lengkap. Akan tetapi untuk soal nomor 4 subjek cenderung menuliskan informasi yang tidak dibutuhkan. Berikut hasil pengerjaan dan wawancara no 4: 
Soal!

4. Pak Budi mempunyai sepetak sawah berbentuk persegi panjang, ia berencana untuk menanami sisi-sisi sawahnya dengan cabe rawit. Luas sawah Pak Budi tidak lebih dari $360 \mathrm{~m}^{2}$ dan panjangnya $30 \mathrm{~m}$. Jika harga bibit cabe rawit siap tanam Rp. 400/pot dan jarak tanamnya $0,5 \mathrm{~m}$. Berapa banyak bibit cabe yang dapat ditanam dan berapa uang yang harus Pak Budi keluarkan untuk membeli bibit?

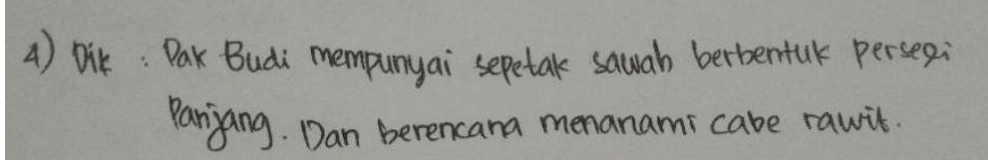

Gambar 3. Lembar Jawaban S9 No.4

Dari gambar 3 terlihat bahwa subjek tidak menuliskan informasi yang dibutuhkan dalam memecahkan masalah. Akan tetapi subjek dapat menyelesaikan soal no.4. dengan demikian pada hasil wawancara menunjukan:

$P$ : "sekarang yang diketahui apa saja?"

$S$ : "Pak Budi mempunyai sawah sepetak sawah berbentuk persegi panjang dan berencana menanami cabe rawit" (Mengidentifikasi Masalah)

$P$ : "menurut kamu informasi yang kamu tulis cukup untuk mengerjakan soal ini?"

$S$ : "engga bu"

$P$ : "terus apa saja informasi yang tidak kamu tuliskan?"

S: "Luas sawah Pak Budi,panjangnya, jarak tanamnya sama harganya ga ditulis"

$P$ : "kenapa tidak kamu tulis? Apakah pada penyelesaian kamu tulis?"

$S$ : "takut ga keburu.. hehe. Ditulis bu, jadi langsung saja dikerjakan"

Pada hasil wawancara subjek dapat menyebutkan informasi yang dibutuhkan untuk memecahkan masalah. Subjek mengungkapkan bahwa subjek langsung menggunakan informasi tersebut pada strategi yang digunakan. Subjek tergesa-gesa untuk segera menemukan solusi. Bransford dan Stein (Patani, 2013) mengungkapkan bahwa kecenderungan ingin cepat menumukan solusi sehingga mengakibatkan tidak memahami masalah dengan lebih komprehensif dan akan berakibat pada langkah selanjutnya. kemudian pada soal nomor 3, Subjek S9 tidak menuliskan salah satu informasi. Ketika diwawancara subjek tidak mengetahui informasi yang dibutuhkan dan mengungkapkan kebingungan dalam menuliskan informasi. Akan tetapi subjek sudah dapat mengidentifikasi masalah ke dalam persamaan atau pertidaksamaan.

Subjek S21 (R) dapat memenuhi indikator mengidentifikasi masalah pada soal 2, 3, dan 4. Pada lembar jawaban untuk ke 3 soal tersebut, subjek hanya menuliskan sebagian informasi akan tetapi ketika diwawancara subjek dapat menyebutkan informasi yang dibutuhkan untuk memecahkan masalah. Selain itu subjek belum dapat mengidentifikasi masalah pada soal akan membentuk persamaan atau pertidaksamaan. Dalam menuliskan informasi yang terdapat dalam soal subjek masih menemui kendala. Kendalanya adalah subjek masih kebingungan menuliskan informasi yang terdapat dalam soal. Hal ini sejalan dengan hasil penelitian oleh (Ermawati, 2018) bahwa kesalahan dalam membaca soal diantaranya siswa tidak dapat memaknai kalimat yang telah dibaca secara tepat. Selain itu (Tomo, 2013) berpendapat bahwa subjek dengan kemampuan rendah tidak dapat 
menunjukan pemahaman masalah karena subjek hanya menuliskan ulang kalimat pada soal.

\section{Mendefinisikan tujuan}

Berdasarkan gambar 2 langkah mendefinisikan tujuan berada pada urutan pertama persentase terbesar yaitu $100 \%$ untuk setiap subjek. Hal ini menandakan bahwa semua subjek dapat mendefinisikan tujuan dengan baik. Ketiga subjek dapat menuliskan tujuan masalah pada soal sesuai dengan masalah pada soal. Akan tetapi cara ketiga subjek dalam menuliskan masalah yang terdapat pada soal berbeda-beda. Terdapat subjek yang menuliskan dengan kalimat sendiri adapula yang menggunakan kalimat pada soal.

Berbeda dengan subjek S14 (T) dan S9 (S), subjek S21 (R) dapat menuliskan permasalahan dengan lengkap. Kalimat yang digunakan dalam menuliskan masalah cenderung masih menggunakan kalimat pada soal. Selain itu subjek S21 tidak menunjukan pemahaman terhadap masalah. Subjek S21 cenderung hanya menuliskan tanpa memahami lebih mendalam mengenai masalah pada soal. Hal ini sejalan dengan penuturan (Istafida, 2018) mengenai kesulitan siswa dalam menyelesaiakan soal cerita adalah siswa masih kesulitan dalam menggunakan data yang diketahui dan kurangnya pemahaman terhadap pertanyaan.

\section{Menggali strategi}

Berdasarkan gambar 2 langkah menggali strategi memiliki hanya subjek S14 (T) yang memiliki persentase terbesar yaitu $100 \%$ artinya subjek mempunyai strategi untuk memecahkan semua soal. Sedangkan S9 (S) hanya memiliki persentase sebesar 25\% artinya hanya 1 soal saja dengan strategi yang benar. Sedangkan untuk subjek S21 (R) sebesar 0\%, artinya subjek tidak memiliki strategi yang benar untuk semua soal.

Subjek S14 (T) memiliki lebih dari satu strategi untuk memecahkan masalah pada tiap soal. Kemudian strategi yang digunakan subjek S14 sistematis dan mengarah pada hasil yang benar sesuai dengan tujuan masalahan pada soal. Pada soal yang membutuhkan rumus matematika yaitu soal 1 dan 4 , subjek S14 subjek dapat menuliskannya dengan benar. Pada soal nomor 2 subjek dapat menggubah permasalahan ke dalam bentuk matematika. Berikut contoh lembar jawaban S14 (T):

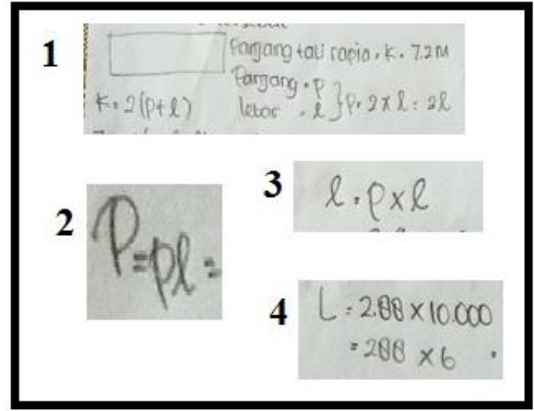

STRATEGI NO.1

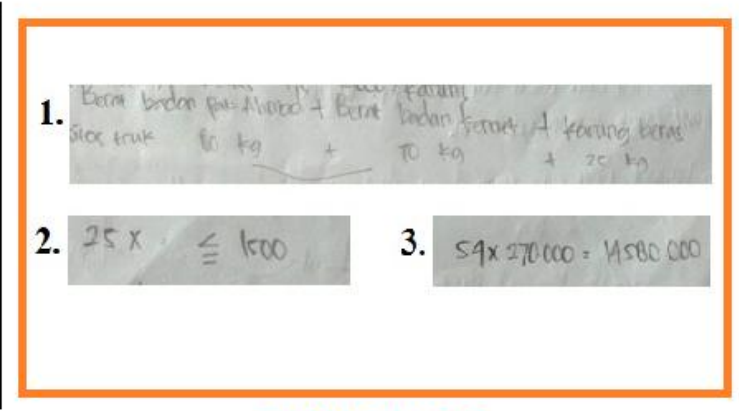

STRATEGI NO.2

Gambar 4. Contoh Strategi S14 
Pada gambar 4 merupakan contoh strategi yang digunakan pada soal 1 dan 2 . Adapaun strategi yang digunakan subjek pada soal nomor 1, 2, dan 4 merupakan strategi kalimat terbuka yang menunjukan bahwa subjek mempunyai kemampuan yang cukup baik dalam memahami setiap informasi. Hal ini sesuai dengan pendapat (Wardhani, 2010) yang menyatakan bahwa dalam menggunakan strategi kalimat terbuka ini melibatkan pemahaman terhadap hubungan dan pertanyaan dalam masalah lalu menerjemahkannya ke dalam bahasa matematika. Selain strategi kalimat terbuka, subjek S14 menggunakan strategi gambar pada soal nomor 1 untuk menggambarkan masalah. (Hartono, 2014) strategi membuat gambar hal ini dilakukan untuk mempermudah mendapat gambaran penyelesaian. Pada soal nomor 3 subjek memakai strategi langsung tanpa mengubahnya ke dalam model matematika strategi menghasilkan jawabann yang benar.

Subjek S9 (S) memiliki strategi yang beragam dalam memecahkan masalah. Terdapat pada dua soal yaitu soal nomor 1 dan 3 subjek S9 (S) mengerjakan langsung dengan mengoperasikan setiap informasi yang telah ditulisnya tanpa mempunyai rencana yang jelas untuk memecahkannya. Berikut lembar jawaban S9 tahap menggali strategi untuk soal nomor 1 dan 3:

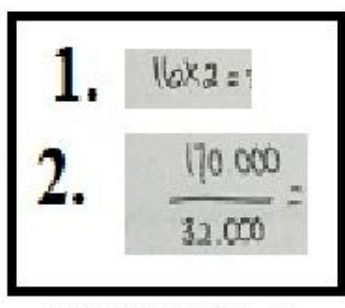

STRATEGI NO.3

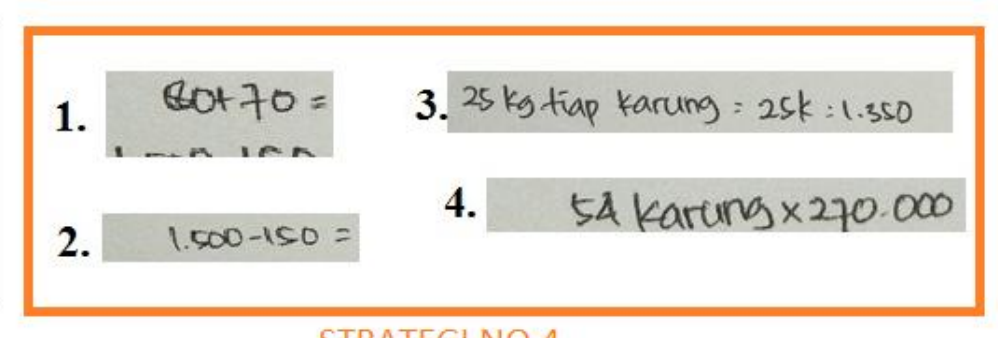

STRATEGI NO.4

Gambar 5. Contoh Strategi S9

Pada gambar 5 terdapat contoh strategi yang digunakan untuk memecahkan masalah. Strategi soal nomor 3 subjek hanya mengoperasikan setiap informasi, kemudian strategi mengarah pada jawaban yang salah. Kemudian untuk soal nomor 2 dan 4 subjek memiliki lebih dari satu strategi untuk memecahkan soal nomor 2 dan 4. Subjek dapat menuliskan persamaan walaupun subjek mengetahui bahwa soal nomor 2 adalah soal pertidaksamaan. Strategi yang digunakan untuk memecahkan masalah nomor 2 ini mengarah pada jawaban yang benar sesuai dengan masalah pada soal. Sedangakan untuk soal nomor 4 berdasarkan pada gambar 4, subjek memiliki lebih satu strategi untuk memecahkan masalah pada soal. Akan tetapi terdapat satu strategi yang keliru. Strategi yang digunakan subjek S9 untuk soal nomor 2 dan 4 menggunakan strategi kalimat terbuka. Menurut (Wardhani, 2010) yang menyatakan bahwa dalam menggunakan strategi kalimat terbuka ini melibatkan pemahaman terhadap hubungan dan pertanyaan dalam masalah lalu menerjemahkannya kedalam bahasa matematika. Hal ini menjelaskan bahwa siswa subjek telah memahami hubungan informasi-informasi yang terdapat pada soal.

Subjek S21 merupakan subjek yang termasuk kategori rendah memiliki strategi hanya pada nomor 1 dan 2 saja. Pada nomor 1 subjek menggambarkan masalah. Menurut (Hartono, 2014) strategi membuat gambar hal ini dilakukan untuk mempermudah 
mendapat gambaran penyelesaian. Akan tetapi subjek hanya menggambarkan saja tanpa memakai strategi lainnya untuk menyelesaikan soal nomor 1. Pada soal nomor 2 subjek memiliki strategi, strategi yang digunakan belum cukup untuk memecahkan masalah pada soal. Strategi yang digunakan pada soal nomor 2 yaitu dengan menggunakan beberapa informasi yang langsung dilakukan operasi hitung. Sedangkan pada nomor 3 dan 4 subjek tidak memiliki strategi yang dapat digunakanya untuk memecahkan masalah. Berdasarkan temuan pada analisis data subjek S21 belum dapat menghubungkan informasi sehingga belum dapat menentukan strategi. Sejalan dengan hasil penelitian (Solaikah, 2013) bahwa dalam merencanakan penyelesaian siswa menggunakan beberapa informasi untuk merencanakan penyelesaian serta kurang mampu merencanakan penyelesaian.

\section{Melaksanakan Strategi}

Berdasarkan gambar 2 langkah melaksanakan strategi memiliki persentase untuk subjek S14 (T) sebesar 75\%,S9 (S) sebesar 25\% dan S21 (R) sebasar 0\%. Untuk S14 (T) hanya 3 soal dapat memenuhi langkah ini. Kemudian untuk subjek S9 (S) hanya 1 soal yang dapat memenuhi langkah ini. Lalu, untuk subjek S21 (R) tidak dapat memenuhi langkah melaksanakan strategi. Subjek S14 (T), dapat melaksanakan seluruh stratagi yang telah dipilihnya. Terdapat kesalahann operasi hitung dalam melaksanakan strategi soal nomor 1 . Seperti yang pada gambar berikut:
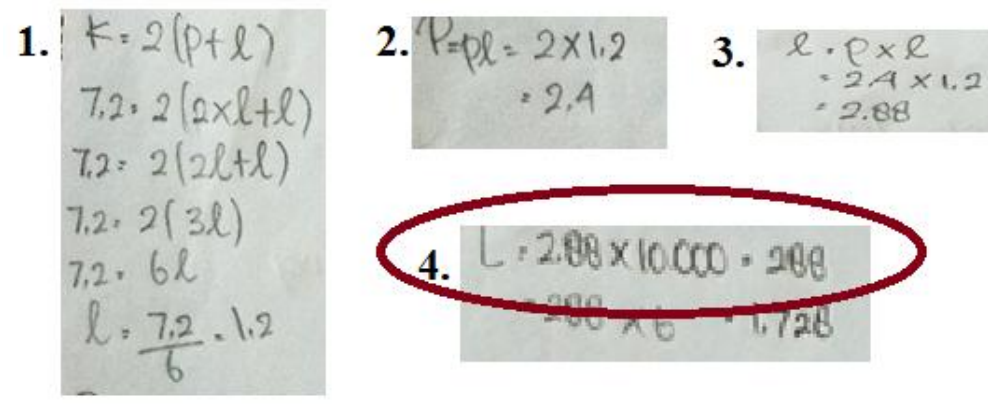

\section{Gambar 6. Contoh melaksanakan strategi S14}

Pada gambar 6 ditunjukan kesalahan yang dilakukan oleh S14 (T). Kesalahan ini terdapat pada soal nomor 1 yang menandakan subjek kurang terampil dalam melakukan operasi hitung. Hal ini sejalan dengan penelitian (Vendiagrys, 2015) yang menyatakan bahwa subjek dapat menempuh seluruh langkah pemecahan masalah yang telah direncanakan akan tetapi sering tidak memperoleh ketetepatan jawaban yang benar penyebabnya siswa kurang terampil dalam berhitung. Sedangkan untuk soal lainnya subjek S14 melaksanakan strategi dengan benar tanpa adanya kesalahan.

Subjek S9 melaksanakan seluruh strategi yang digunakannya. Dalam melaksanakan strategi soal nomor 2 menggunakan strategi kalimat terbuka dan tidak terdapat kesalahan dalam operasi hitung. Untuk soal 1 dan 3 dengan strategi yang salah subjek 9 tidak terdapat kesalahan dalam melakukan perhitungan. Kemudian untuk soal nomor 4 strategi yang dipakai belum mendapatkan solusi, tidak terdapat kesalahan perhitungan. 
Subjek S21 melaksanankan strategi hanya pada nomor 2 saja. Selain melaksanakan strategi yang kurang tepat subjek melakukan kesalahan dalam melakukan operasi hitung. Subjek dapat menggunakan beberapa informasi akan tetapi tidak menghasilkan solusi untuk nomor 2. Sejalan dengan penelitian (Poima, 2016) bahwa subjek rendah masih kesulitan dalam memenuhi langkah melaksanakan strategi.

\section{Mengkaji kembali}

Berdasarkan gambar 2, langkah ini memiliki persentase untuk subjek S14 (T) sebesar 75\%, S9 (S) sebesar 25\% dan S21 (R) 0\%. Untuk S14 (T) artinya subjek hanya pada 3 soal dapat memenuhi langkah ini. Kemudian untuk S9 (S) hanya 1 soal yang dapat memenuhi langkah ini dan untuk subjek S21 (R) tidak dapat memenuhi langkah ini untuk setiap soal. Selain itu persentase rendah ini menunjukan masih banyak kesalahan yang dilakukan ketika melewati langkah ini atau masih ada yang tidak melewati langkah ini.

Subjek S14 (T) dapat menarik simpulan dari hasil yang telah diperolehnya pada semua soal. Simpulan yang dituliskan subjek sesuai dengan masalah yang terdapat pada soal. Pada soal nomor 1 simpulan yang dihasilkan subjek bernilai salah hal ini diakibatkan oleh kurang telitinya subjek dalam menggunakan operasi hitung. Subjek S14 mengecek kembali dalam penulisan dan operasi hitung. Hal ini sejalan dengan penelitian yang dilakukan oleh (Solaikah, 2013) bahwa subjek dengan kemampuan tinggi dapat memeriksa kembali jawaban pada proses dan hasil serta membuat simpulan sesuai dengan soal.

Subjek S9 (S) dapat menarik simpulan dari hasil yang telah diperolehnya pada semua soal. Simpulan yang dituliskan subjek terdapat simpulan yang benar dan simpulan yang salah. Simpulan yang benar hanya terpadat pada soal nomor 2 saja. Selain dari nomor 2 simpulan yang dihasilkan salah. Berdasarkan hasil analisis subjek melakukan pengecekan ulang pada bagian operasi perhitungan. Sejalan dengan penelitian yang dilakukan oleh (Solaikah, 2013) bahwa subjek berkemampuan sedang dalam memeriksa kembali hasil yang diperoleh siswa melakukan pengecekan kembali pada proses dan jawaban serta membuat sebuah kesimpulan.

S21 (R) dapat menarik simpulan 3 saja. Pada nomor 3 simpulan yang dituliskan subjek termasuk solusi yang benar akan tetapi simpulan yang dituliskan belum dapat dipertanggung jawabkan karena subjek tidak mempunyai rencana dalam menyelesaikan soal. Untuk soal nomor 2 subjek mempunyai strategi dan melaksanakan strateginya akan tetapi strategi yang dipilih belum dapat memecahkan masalah. Kemudian subjek tidak melakukan menarik simpulan dan melakukan pengecekan. Sejalan dengan penelitian (Solaikah, 2013) bahwa subjek berkemampuan rendah tidak melakukan pengecekan kembali pada proses dan jawaban serta tidak membuat sebuah kesimpulan.

\section{Kesimpulan}

Berdasarkan hasil penelitian dan pembahasan serta mengacu pada tujuan penelitian, maka dapat disimpulkan sebagai berikut:

1. Mengidentifikasi masalah

Subjek berkemampuan tinggi dapat mengidentifikasi masalah dengan baik pada setiap nomor pemecahan masalah dengan menuliskan semua informasi yang dibutuhkan dalam 
memecahkan masalah. Kemudian subjek berkemampuan sedang dan rendah dapat mengidentifikasi masalah dengan baik pada beberapa soal saja.

2. Mendefinisikan tujuan

Semua subjek dapat mendefinisikan tujuan masalah pada semua soal yang diteskan dengan menuliskan tujuan masalah sesuai dengan permasalahan pada soal. Semua subjek memahami masalah dan mengerti maksud masalah pada soal.

3. Menggali Strategi

Subjek berkemampuan tinggi memiliki lebih dari satu strategi yang digunakan untuk setiap soal dan mengarah pada jawaban yang benar strategi yang digunakan strategi gambar dan kalimat terbuka. Subjek berkemampuan sedang hanya dapat memilih strategi yang benar hanya pada satu nomor, adapun strategi yang digunakan adalah strategi kalimat terbuka. Sedangkan untuk subjek berkemampuan rendah tidak memiliki strategi yang benar. Subjek mempunyai strategi untuk soal nomor 1 dan 2 akan tetapi stategi belum tepat. Strategi yang digunakan strategi gambar dan kalimat terbuka

4. Melaksanakan strategi

Subjek berkemampuan tinggi hanya dapat melaksanakan strategi yang benar pada 3 soal yang diteskan dan terdapat kesalahan operasi hitung pada satu nomor. Kemudian subjek berkemampuan sedang melaksanakan strategi yang benar tidak melakukan kesalahan. Dalam melaksanakan strategi yang salah subjek tidak melakukan kesalahan operasi hitung. Sedangkan untuk subjek berkemampuan rendah melaksanakan strategi yang salah dan masih terdapat kesalahan operasi hitung.

5. Mengkaji Kembali

Tidak semua subjek dapat melaksanakan langkah ini. Subjek berkemampuan tinggi melakukan pengecekan hanya pada 3 soal yang diteskan. Pengecekan dilakukan dengan melihat kembali langkah pengerjaan dan operasi hitung. Dapat membuat simpulan untuk semua soal dan sesuai dengan tujuan masalah. Subjek berkemampuan sedang hanya mengecek kembali hanya pada satu soal. Sedangkan untuk subjek berkemampuan rendah tidak melaksanakan tahapan ini pada semua soal.

\section{DAFTAR PUSTAKA}

Annizar, A. M. (2015). Analisis Kemampuan Pemecahan Masalah Soal Pisa Menggunakan IDEAL Problem Solving pada siswa usia 15 tahun di SMA Nuris Jember. Universitas Jember.

Arikunto, S. (2010). Dasar-dasar Evaluasi Pendidikan. Jakarta: Rineka Cipta.

Ermawati. (2018). Bentuk Kesalahan dalam Menyelesaikan Soal Cerita Matematika. Retrieved July 13, 2018, from http://kompasiana.com/ermaw/bentuk-kesalahan-dalammenyelesaikan-soal-cerita

Hartini, S. (n.d.). Psikologi Pendidikan. Surakarta: BP-FKIP UMS.

Hartono, Y. (2014). Matematika: Strategi Pemecahan Masalah. Yogyakarta: Graha Ilmu. Yogyakarta: Graha Ilmu.

Istafida. (2018). Pembahasan Soal cerita Matematika Kelas 4 SD. Retrieved July 9, 2018, 
from http://rumusonline.com/947/pembahasan-soal-cerita-matematika-kelas-4-sd

Nahdataeni, S. S., \& Linawati. (2015). Proses Berpikir Siswa dalam Memecahkan Masalah Sistem Persamaan Linier Dua Variabel Ditinjau dari Gaya Belajar di Kelas X SMA Negeri 2 Palu. AKSIOMA Jurnal Pendidikan Matematika, 4(2).

Nissa, I. C. (2015). Pemecahan Masalah Matematika Teori dan Praktik. (D. P. Ilmu, Ed.). Mataram.

Patani, M. (2013). Upaya Meningkatkan Kemampuan Problem Solving Pada Mahasiswa Fakultas Psikologi Universitas YARSI. Jurnal Psikogenesis, 1(2).

Poima, D. M. (2016). Profil Pemecahan Maslaah Matematika Pada Materi Perbandingan Dan Skala Berdasarkan Tahapan Polya Bagi Siswa Kelas VI SD Kristen 03 Eben Haezer Salatiga. Universitas Kristen Satya Wacana Salatiga.

Prasetya, A. K., \& Widodo, A. . (2012). IDEAL Problem Solving untuk Mencapai Kemampuan Pemecahan Masalah Siswa di Kelas Olimpiade. Jurnal Lembaran Ilmu Kependidikan, 41(1), 1-6.

Purnomo, E. ., \& Mawarsari, V. . (2014). Peningkatan Kemampuan Pemecahan Masalah melalui Model Pembelajaran IDEAL Problem Solving Berbasis Project Based Learning. Jurnal JKPM, 1(1), 25-31.

Solaikah. (2013). Identifikasi Kemampuan Siswa dalam Menyelesaikan Soal Aritmatika Sosial Ditinjau dari Perbedaan Kemampuan Matematika. Jurnal Pendidikan Matematika STKIP PGRI Sidoarjo, 1(1), 2013.

Sugiyono. (2017). Metode Penelitian Kuantitatif, Kualitatif dan $R \& D$. Bandung: Alfabeta.

Tomo. (2013). Kemampuan Pemecahan Masalah Siswa Pada Materi Bangun Datar Di SMP. Untan.

Ulya, H. (2015). Hubungan Gaya Kognitif dengan Kemampuan Pemecahan Masalah Matematika Siswa. Jurnal Konseling, 1(2), 2015.

Vendiagrys. (2015). Analisis Kemampuan Pemecahan Masalah Matematika Soal setipe TIMSS berdasarkan Gaya Kognitif Siswa pada Pembelajaran Problem Based Learning. Unnes Journal of Mathematics Education Research, 4(2), 31-34.

Wardhani, S. (2010). Pembelajaran Kemampuan Pemecahan Masalah Matematika Di SMP.

Widodo, P., \& Purwaningsih, I. E. (2016). Pengaruh Media Komik terhadap Kemampuan Pemecahan Masalah dan Prestasi Belajar Matematika Ditinjau dari Kemampuan Awal Siswa Kelas VIII. In Prosiding Seminar Nasional Matematika dan Pendidikan Matematika UNY. Yogyakarta. 